\title{
Development of Organic Agriculture in the Mekong Delta - Opportunities and Challenges
}

\author{
Cong Thanh Nguyen and Tran Thi Tuyet Van
}

\begin{abstract}
The model of organic rice production in the Mekong Delta, which started from 2015 until now (2020), has had good results. Organic agriculture still faces many difficulties and challenges at the beginning but many of them have been solved out. First of all, that is the success of organic rice production in the shrimp-rice area with the potential of hundreds of thousands of hectares. Then, the replication of organic rice production in the intensive practice areas and the replication of organic production for other crops have high economic value. The SWOT research and analysis showed that the development of organic agriculture still has many weaknesses and threats compared to strengths and opportunities. The biggest weaknesses and threats are the difficulties in changing social awareness and in changing farming practices of farmers. Farmers who are accustomed to traditional production which highly application of chemical fertilizers and chemical pesticides, it is not easy work to change their traditional practices to organic practices. At the same time, there are some cases that farmers are dishonest, they do not follow the process or arbitrarily apply forbidden chemical inputs leading to failure of the model which affects the whole project and harms the invested businesses. The next challenge is weed management in organic rice production, especially in intensive rice cultivation areas in which paddy grows 2-3 crops for a year. That is because in organic production no chemical herbicides are allowed. Weaknesses and threats lead to many risks, making businesses and stakeholders afraid to invest in organic production. For strengths and opportunities, the Vietnam government has made new policies to encourage the development of organic agriculture for the Mekong Delta and the whole country. Besides that, due to the demand for organic products, organic product consumption becomes a hot trend in the world and the country now a day, opening up a great opportunity for the production and trading of organic products. To overcome weaknesses and threats to take advantage of opportunities for organic agriculture, the authors have proposed recommendations to create solutions for organic agriculture in Mekong Delta to develop.
\end{abstract}

Keywords: challenge, Mekong Delta, Organic farming, Opportunity, shrimp-rice farming.

\section{INTRODUCTION}

According to The International Federation of Organic Agriculture Movements (IFOAM), Organic agriculture is a combined farming system towards sustainability, enhancement of soil fertility and biodiversity. This cultivation prohibits the use of chemical pesticides, antibiotics, chemical fertilizers, genetically modified varieties, and growth hormones.

According to Nguyen Cong Thanh [1], organic agriculture is understood as a combination of tradition and modernity in

Published on July 22, 2021.

Cong Thanh Nguyen, Asian Organic Agriculture Research and Development Institure (AOI), Vietnam. which advances of high technologies such as biotechnology, mechanical technology are applied along with conserving biodiversity in farming to stabilize or increase yields of crops and livestock without applying chemical fertilizers, chemical pesticides, chemical herbicides, growth hormones, toxic antibiotics, and genetically modified varieties. These are replaced by recognized organic and biological inputs to protect human health, ecological environment, and nature towards quality, value, humanity, efficiency, sustainability, and happiness for all species on the earth.

Wood et al. [2] and Millennium Ecosystem Assessment [3] have selected some important findings highlighting the longterm impact of agriculture and related activities on natural resources such as moderate to severe soil degradation occurs on $52 \%$ of global agricultural lands; The flow of nitrogen to the oceans has doubled since 1860; The number of species on the planet is declining and the species distribution is becoming more homogenous; Genetic diversity has declined globally, particularly among cultivated species, etc.

The tradition in agriculture has been to maximize production and minimize the cost of food with little regard to impacts on the environment and the services it provides to society. As the world enters an era in which global food production is likely to double, agricultural practices be modified to minimize environmental impacts even though many such practices are likely to increase the costs of production [4].

According to United Nations Thematic Group [5], environmental degradation is a big problem today. They have quoted that "after half a century of highly intensive input agriculture, the yield gap between best practices and farmers' fields remains large, agricultural lands continue to shrink and global environmental threats are a reality, e.g. erosion of biodiversity, desertification, climate change, and other transboundary pollution. Agriculture intensification contributes to over $20 \%$ of global anthropogenic greenhouse gas emissions. Agricultural activities affect $70 \%$ of all threatened bird species and $49 \%$ of all plant species. Uniform cultures have dramatically reduced the number of plants and animals used in agriculture; currently, 1,350 breeds face extinction, with two breeds being lost each week. Biodiversity erosion is exacerbated by the loss of forest cover, coastal wetlands and other wild relatives, important for the development of biodiversity and essential for food provision, particularly in times of crisis."

Tran Thi Tuyet Van, An Giang University (AGU), Vietnam.

(e-mail: nguyencongthanhct@ gmail.com)

(corresponding e-mail: tttvan@agu.edu.vn) 


\section{A. Why Must Do Organic Agriculture?}

Nguyen Cong Thanh [1] summarized the reasons need to do organic agriculture as below.

- Avoid toxic chemicals from fertilizers and pesticides.

- Mitigating the effects of Climate Change.

- Preserving the environment and the planet for present and future generations.

- Accumulate benefits from healthier nutrients.

- Stay away from genetically modified organisms (GMO) foods.

- Make the food taste more delicious and natural.

- Direct support to farmers.

- Preserve agricultural biodiversity.

- Preventing antibiotics, growth hormones in animal and plant products.

- Ensuring the true value of organic produce "Less is more", no hidden costs.

- Ensuring reliability with high standards (international standards).

- Take care of animals better and be good for wild animals.

- Ensuring moral, humanistic, and fairness for all species.

Kristiansen P., Taji A. and Reganold J. [6] have summed up the benefits and opportunities for organic agriculture are as follow:

- Provision of ecological services, such as crop protection, yield stability, and system resilience.

- Reduced chemical residues in food and the environment.

- Few strongly negative environmental impacts.

- Economic performance is often equivalent to conventional farming.

- High standards of animal welfare.

- Reliable and credible standard-setting processes and certification schemes.

- Dynamic review of policies and standards.

- Strong consumer demand and brand recognition.

- Indigenous knowledge is valued.

- Potential for cooperative rural and regional development.

Despite the generally positive outlook, the organic movement faces several hurdles as it expands internationally. A recent review of organic farming listed several threats facing organic agriculture according to Halberg et al. [7] including: (i) ecological justice; (ii) animal welfare; (iii) fair trade; (iv) supply chain development; (vi) productivity limitations; and (vii) regional adaptation and global harmonization for standards.

According to Kristiansen P., Taji A. and Reganold J. [6]: "Organic agriculture will continue to challenge its critics as increasing numbers of successful enterprises are established in various countries. Organic proponents will also be challenged as new ethical questions emerge and the task of reviewing and improving organic farming methods is tackled. The organic movement has grown beyond its roots of farmers, growers groups, and loyal consumers to a global niche industry. With new stakeholders and different stakes, the organic movement now has the opportunity to form more beneficial relationships and interact more directly with all key players in agricultural development."

\section{Methodology}

The authors have synthesized the results of building organic rice production models on large scale at different locations in the Mekong Delta from 2015 to 2018. Thereby, evaluating the achieved results and analyzing strengths, weaknesses, opportunities, and threats for organic agricultural development in the Mekong Delta could be carried out.

To evaluate the efficiency of building organic rice models, the authors selected the main parameters for analysis such as Total cost (VND/ha); Productivity (kg/ha); Selling price (VND /kg); Total income (VND/ha); Profit (VND /ha); Cost prices (VND / kg); Profit/kg of rice (VND/kg) and capital efficiency or marginal benefit-cost ratio (MBCR) to calculate and include in report tables and design graphs to interpret the analysis of the model results. At the same time, it is compared with the inorganic model in the same locations of the project.

To study and analyze the SWOT (strengths, weaknesses, opportunities, and threats), through seminars and conferences, the authors' group has synthesized opinions from many different sources and divisions in the value chain system. Research and questionnaires were used for individuals to express weaknesses, threats, strengths, and opportunities in organic agricultural production in general and organic rice in particular.

\section{RESULTS AND DISCUSSION}

A. Development of Organic Rice in Mekong Delta

1. The progress of organic agriculture development in Mekong Delta

Up to now, the community organic rice in the Mekong Delta has grown very excitedly, from a few tens of hectares in Chau Thanh district, Tra Vinh province carried out by the research team in the Institute of Agricultural Sciences for Southern Vietnam (IAS) leaded by Nguyen Cong Thanh, has been successfully certified by EU, USDA and JAS organic standards. Up to now, many provinces have developed organic rice with an area of over 1000 hectares. Most of them are in the shrimp-rice farming systems and also in the intensive rice cultivation areas with 2-3 crops for a year as the case in Vinh Long province. To replicate the organic rice farming, researchers from IAS accompany with the businesses, and NGOs like Oxfam have implemented the project of linking organic rice production and market from 2018 to 2020. The result for organic rice farming development in Mekong Delta is showed in the map (Fig. 1).

Rice is cultivated according to the organic standards in the shrimp-rice system with the accredited international organic certification. That is in the provinces of Ben Tre, Tra Vinh, Soc Trang, Ca Mau, and Kien Giang.

Rice is cultivated according to the organic standards in the shrimp-rice system. However, it has not been certified organic standards yet. That is in Bac Lieu province.

Rice is cultivated according to the organic standards in the intensive areas with 2-3 crops for a year. It has not met the organic standards. That is a case in An Giang and Kien Giang provinces. 


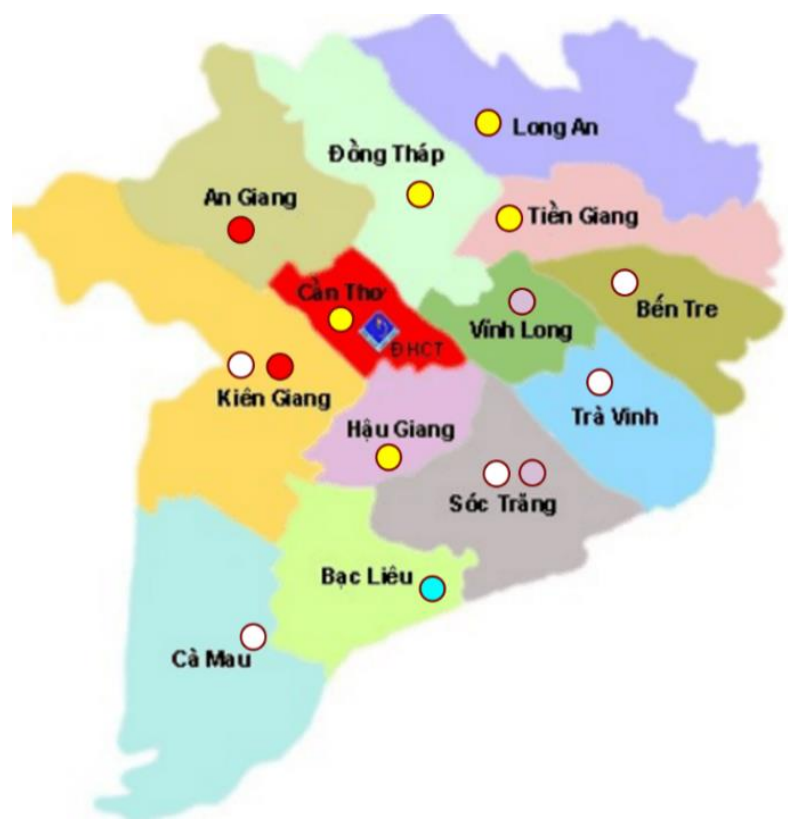

Fig. 1. The progress of organic rice development in Mekong Delta.

Rice is cultivated according to the organic standards in the intensive areas with 2-3 crops for a year. International organic certification is accredited. This is a case of Tan Dat cooperative in Vinh Long province. The success of the model is due to the close cooperation of the "four partners" Including Ocean Xanh Import \& Export Co., Ltd (enterprise), Tan Dat Agricultural Service and Production Cooperative (farmer), AOI Institute (scientist), and Vinh Long Government (government), in which role of the enterprise and the cooperatives is the most important. The success of the model confirms that the rice organic model in intensive rice production areas with the close cooperation of the "four partners" could be replicated in different places in Mekong Delta.

There is no organic rice farming model in these areas. However, these provinces also have proposed programs to develop safe and organic rice.

2. General statistics of enterprises linking farmers to produce and consume organic rice in the Mekong Delta

Regarding the area of organic rice cultivated according to the international standards such as EU, USDA, and JAS in the Mekong Delta is summarized in Table I. There are 10 companies involved in building organic rice model with a total area is 2.090 hectares, therein 100 hectares have not been certified yet.

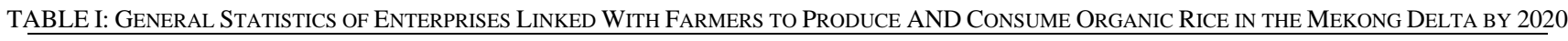

\begin{tabular}{|c|c|c|c|c|c|}
\hline No. & Company Name & Address & Cultivation Areas & $\begin{array}{l}\text { Acreage } \\
\text { (ha) }\end{array}$ & Start time \\
\hline 1 & EcoTiger Co., Ltd. & $\begin{array}{l}\text { No. 14, Street No. 3, Cityland Residential Area, } \\
\text { Tan Phu Ward, District 7, Ho Chi Minh City }\end{array}$ & $\begin{array}{l}\text { Chau Thanh District, Tra } \\
\text { Vinh Province }\end{array}$ & 300.00 & From 2015 \\
\hline 2 & $\begin{array}{l}\text { TAN HONG FOOD Co., } \\
\text { Ltd. }\end{array}$ & $\begin{array}{l}\text { No. 28, Lot F, Tan Thuan Hamlet, An Hoa Ward, } \\
\text { Sa Dec City, Dong Thap Province }\end{array}$ & $\begin{array}{l}\text { Chau Thanh District, Tra } \\
\text { Vinh Province }\end{array}$ & 50.00 & From 2016 \\
\hline 3 & $\begin{array}{l}\text { Hoa Nang Agricultural Co., } \\
\text { Ltd. }\end{array}$ & $\begin{array}{l}\text { 110/26-110/28 Ong Ich Khiem Street, Ward 5, } \\
\text { District 11, Ho Chi Minh City }\end{array}$ & Ben Tre Province & 200.00 & From 2017 \\
\hline 4 & Co May Co., Ltd. & $\begin{array}{l}\text { No.186, The } 80 \text { National Highway, Thanh Phu } \\
\text { Hamlet, Tan Binh Commune, Chau Thanh District, } \\
\text { Dong Thap Province }\end{array}$ & Ca Mau Province & 300.00 & From 2018 \\
\hline 5 & $\begin{array}{l}\text { Blue Ocean Import Export } \\
\text { Co., ltd }\end{array}$ & $\begin{array}{l}\text { No. 52, Street 10, Him Lam Residential Area, Tan } \\
\text { Hung Ward, District 7, Ho Chi Minh City }\end{array}$ & $\begin{array}{c}\text { Tri Ton District, An Giang } \\
\text { Province }\end{array}$ & 100.00 & Not certified \\
\hline 6 & $\begin{array}{l}\text { Blue Ocean Import Export } \\
\text { Co., ltd }\end{array}$ & $\begin{array}{l}\text { No. 52, Street 10, Him Lam Residential Area, Tan } \\
\text { Hung Ward, District 7, Ho Chi Minh City }\end{array}$ & $\begin{array}{l}\text { Vung Liem District, Vinh } \\
\text { Long Province } \\
\text { Nga Nam District, Soc } \\
\text { Trang Province }\end{array}$ & 50.00 & From 2017 \\
\hline 7 & TV FOOD Co., Ltd. & $\begin{array}{l}\text { Nhon Hoa Hamlet, Nhon My Commune, Cho Moi } \\
\text { District, An Giang Province }\end{array}$ & $\begin{array}{l}\text { Thoi Binh District, } \mathrm{Ca} \\
\text { Mau Province } \\
\text { An Bien District, Kien } \\
\text { Giang Province }\end{array}$ & 450.00 & From 2017 \\
\hline 8 & $\begin{array}{l}\text { Ho Quang Tri Private } \\
\text { Enterprise }\end{array}$ & $\begin{array}{l}196 \text { Provincial Road 8, Ha Bo Hamlet, Tai Van } \\
\text { Village, Tran De District, Soc Trang Province }\end{array}$ & $\begin{array}{l}\text { My Xuyen District, Soc } \\
\text { Trang Province }\end{array}$ & 20.00 & From 2017 \\
\hline 9 & $\begin{array}{c}\text { Trung An Hi - Tech Farming } \\
\text { JSC. } \\
\text { Total }\end{array}$ & $\begin{array}{c}\text { 649A, Highway 91, Trung Kien Ward, Thot Not } \\
\text { District, Can Tho City }\end{array}$ & $\begin{array}{l}\text { Hon Dat Disctrict, Kien } \\
\text { Giang Province } \\
06 \text { provinces }\end{array}$ & $\begin{array}{c}100.00 \\
2.044 .10\end{array}$ & -NA- \\
\hline
\end{tabular}

3. Introduction of some typical organic rice models in the Mekong Delta

3.1. Organic rice model in shrimp - rice system in Cau Ngang district, Tra Vinh province

Regarding yield in the case of the pilot model in Cau Ngang district, Tra Vinh province in 2017, the yield of organic rice in the model is $300 \mathrm{~kg} / \mathrm{ha}$ higher than the rice out of model. Combining the advantage of the purchasing price of the linked company (Dai Duong Xanh Import-Export Limited Company) is higher $1,400 \mathrm{VND} / \mathrm{kg}$ than rice out of the model, the profit of farmers participated in the model was increased nearly 5.44 million VND/ha. The equity efficiency for the organic rice model is 1.0 which higher than inorganic rice out of the model is 0.2 times.

TABLE II: EFFICIENCY OF ORGANIC RICE MODEL COMPARED TO MASS PRODUCTION IN CAU NGANG DISTRICT, TRA VINH, 2017

\begin{tabular}{cccccc}
\hline Model & $\begin{array}{c}\text { Yield } \\
\text { (ton/ha) }\end{array}$ & $\begin{array}{c}\text { Selling Price } \\
\text { (VND/kg) }\end{array}$ & $\begin{array}{c}\text { Total Income (mil. } \\
\text { VND/ha) }\end{array}$ & $\begin{array}{c}\text { Profit } \\
\text { (mil. VND/ha) }\end{array}$ & $\begin{array}{c}\text { Equity } \\
\text { Efficiency }\end{array}$ \\
\hline Organic rice & 5.30 & 7.000 & 37,100 & 18,295 & 1.00 \\
Inorganic rice & 5.00 & 5.600 & 28,000 & 12,900 & 0.80 \\
Difference & 0.30 & 1.400 & 9,100 & 5,395 & 0.20 \\
\hline
\end{tabular}




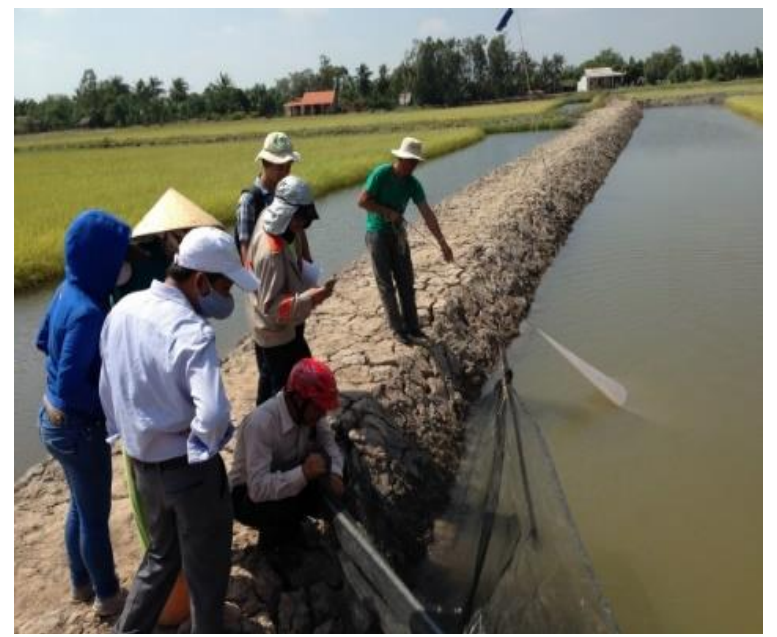

Fig. 2. Control Union's staff is auditing at organic rice model in Cau Ngang district, Tra Vinh province in 2017.

3.2. Organic rice model in shrimp - rice system in a Minh district, Kien Giang province

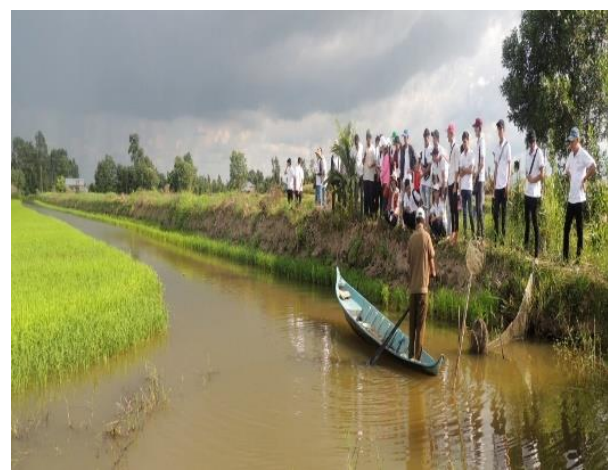

Fig. 3. AGU students are taking a study tour at organic rice model in an Minh district, Kien Giang province.

Evaluation of the efficiency of the organic rice model versus inorganic rice production in An Minh district, Kien Giang province in 2017, the cooperation model between Gentraco Corporation and the Thanh An Cooperative, shows that the total production cost of Mot Bui Do variety in inorganic farms is $14 \%$ higher than that of ST24 variety grown in organic farms. Low production costs in organic farming dues to lower costs of seeds, fertilizers, and pesticides. Meanwhile, labor costs are equal between organic certification were encouraged by the company to reward an additional $20 \%$ of the selling price, resulting in a $39 \%(7,397$ million VND/ha) increase in profits from off-model.

Evaluation of the efficiency of the organic rice model versus inorganic rice production in An Minh district, Kien Giang province in 2017, the cooperation model between Gentraco Corporation and the Thanh An Cooperative, shows that the total production cost of Mot Bui Do variety in inorganic farms is $14 \%$ higher than that of ST24 variety grown in organic farms. Low production costs in organic farming dues to lower costs of seeds, fertilizers, and pesticides. Meanwhile, labor costs are equal between the two models. For yield comparison, ST24 in organic rice farms is $700 \mathrm{~kg} / \mathrm{h}$ a lower than Mot Bui Do in inorganic farms 17\%. In terms of profit, in the market, the price of ST24 is higher than Mot Bui Do, so that the profit per hectare of ST24 in organic farms is higher $14 \%$ (1,868 million VND/ha). Furthermore, when farmers participated in the organic model, the price will be added for more $500 \mathrm{VND} / \mathrm{kg}$, resulting in a profit increased of $25 \%$ (3,969 million VND/ha) higher than the model. The farmers who obtained organic certification were encouraged by the company to reward an additional $20 \%$ of the selling price, resulting in a 39\% (7,397 million VND/ha) increase in profits from off-model.

TABLE III: ECONOMIC EFFICIENCY OF ORGANIC RICE MOdEL IN AN MinH DISTRICT, KIEN GIANG PROVINCE, 2017

\begin{tabular}{|c|c|c|c|c|}
\hline \multirow[t]{2}{*}{ No. } & \multirow[t]{2}{*}{ Content } & \multicolumn{2}{|c|}{$\begin{array}{l}\text { Production cost (mil. } \\
\text { VND/ha) }\end{array}$} & \multirow{2}{*}{$\begin{array}{c}\text { Difference between } \\
\text { organic rice (ST24 } \\
\text { variety) with } \\
\text { inorganic rice (Mot } \\
\text { Bui Do variety) (\%) }\end{array}$} \\
\hline & & $\begin{array}{l}\text { Organic } \\
\text { rice }\end{array}$ & $\begin{array}{l}\text { Inorganic } \\
\text { rice }\end{array}$ & \\
\hline I & $\begin{array}{l}\text { Total cost (mil. } \\
\text { VND/ha) }\end{array}$ & 12.150 & 13.850 & (-) 14.0 \\
\hline 1 & Fertilizer & 3.500 & 3.850 & (-) 10.0 \\
\hline 2 & $\begin{array}{l}\text { Pesticide and } \\
\text { herbicide }\end{array}$ & 0.300 & 1.150 & (-) 283.3 \\
\hline 3 & Seeds & 1.500 & 2.000 & (-) 25.0 \\
\hline 4 & Labor cost & 6.850 & 6.850 & 0.0 \\
\hline II & $\begin{array}{l}\text { Average yield } \\
\text { (ton/ha) }\end{array}$ & 4.200 & 4.900 & (-) 17.0 \\
\hline III & $\begin{array}{l}\text { Total income (mil. } \\
\text { VND/ha) }\end{array}$ & 25.648 & 25.480 & (+) 0.6 \\
\hline 7 & $\begin{array}{c}\text { Profit/ha } \\
\text { - According to } \\
\text { market price } \\
\text { - Adding } 500 \\
\text { VND/kg } \\
\text { - Adding more } 20 \%\end{array}$ & $\begin{array}{l}13.498 \\
15.599 \\
19.009\end{array}$ & $\begin{array}{l}11.630 \\
11.630 \\
11.630\end{array}$ & $\begin{array}{l}(+) 14 \\
(+) 25 \\
(+) 39\end{array}$ \\
\hline
\end{tabular}

Note: The selling price of paddy in the market at the harvest time: ST24 rice variety is $6,100 \mathrm{VND} / \mathrm{kg}$; Mot Bui Do variety is $5,200 \mathrm{VND} / \mathrm{kg}$; adding 500 $\mathrm{VND} / \mathrm{kg}$ for farmers engaged in organic rice production, so the price of the organic rice ST24 after adding is $6,607 \mathrm{VND} / \mathrm{kg}$; then if rice got the organic certification, the price will be added more $20 \%$, so the final price is 7,928.4 VND/kg.

\subsection{Organic rice model in intensive farming areas (Vinh} Long, Kien Giang, Soc Trang provinces)

Comparing the investment and cost efficiency, the model in My Xuyen is the lowest with 20.3 million VND/ha; followed by Tan Dat Cooperative with 22.5 million VND/ha and Tan Hiep is highest with 28.62 million VND/ha. Regarding rice yield, rice yield in Tan Dat Cooperative is the lowest at 4 tons/ha while in My Xuyen is 4.3 tons/ha and in Tan Hiep is 5.0 tons/ha. The selling price of organic rice in Tan Dat Cooperative is $8,700 \mathrm{VND} / \mathrm{kg}$, equivalent to Tan Hiep 8,700 VND/kg. And in My Xuyen, the rice price is highest at $8,000 \mathrm{VND} / \mathrm{kg}$. Meanwhile, the price of inorganic paddy on the market ranges from 4,500-5,200 VND/kg. Results lead to the difference in profit compared to inorganic rice outside the model in Tan Dat Cooperative was 3.6 million VND/ha; in My Xuyen is 1.1 million VND/ha and in Tan Hiep is 1.95 million VND/ha.

\section{B. Organic Agriculture - Opportunities and Threats}

To study SWOT, the authors have synthesized opinions from many different sources and divisions in the value chain system through seminars and conferences and combining them with research. The questionnaires were given to individuals to express weaknesses, threats, strengths, and opportunities in organic rice production. The result is showed in Table $\mathrm{V}$. 
From Table V, there are still many weaknesses and threats compared to strengths and opportunities. The biggest weakness and threats are the difficulty in changing social awareness and changing farming practices of farmers. To change social awareness requires a long-term investment in propaganda and education to change the social perception. And to change the farming practices of farmers is also need a long time to persuade and educate them. Over a long history, farmers who are accustomed to production which using a lot of chemical fertilizers and pesticides to protect plants and increase yield so that to ask them to convert into organic production is a one-a-day story. The reason is lack of trust and knowledge of farmers, besides due to the low efficiency of the organic inputs for organic rice production compare with chemical inputs.

At the same time, the difficulty is that there are cases where farmers are dishonest, they do not follow the process or arbitrarily apply banned chemical inputs in organic production, which will lead to failure of the model and affects the entire project, and harms to investment businesses.

The next challenge is weed management in rice production, especially in intensive rice production areas with 2-3 rice crops for a year. Since organic production is completely clean, no chemical herbicides are allowed. While bio-herbicides are not popular, farmers are accustomed to using chemical herbicides to control weeds up to 2-3 times for a rice crop. In the shrimp-rice system, weed control is relatively better because farmers will grow shrimp after the rice crop. Using chemical herbicide or pesticide will affect the shrimp growth so that the farmers never use them in this region [8].

In summary, the weaknesses and threats are many and these threats lead to many risks, making businesses and stakeholders in the value chain afraid to invest in organic production.

To further illustrate the weaknesses and threats, we supplement the research data over the years from 2015 to the present (2020) on the cases of non-compliance (violation of the application of banned substances in organic rice production). The results of monitoring of noncompliance and risk were recorded in Table VI for the period 7 years with 7 models in 7 different locations. The number of farmers participating in the model ranged from 3-45 households per model and the average for each model is 15 households. Violating farmers ranged from 1-10 cases, an average of 4.1 cases per model. Thus, the number of farming households violating is quite high. However, these are the cases recorded in the first year of model construction, the years later have been re-selected and at the same time, farmers' awareness has improved. However, there are still a few cases where there are violations even though many cases have passed the organic certification. Therefore, the experience and skills of the consultant bodies and the enterprises play an important role in building a model to overcome these weaknesses and threats.

The strengths and opportunities in developing organic agriculture in the Mekong Delta and the country recently are very good. That is due to the policy and encouragement policy of the Government of Vietnam which has many new policies have been made to encourage the development of organic agriculture. At the same time, there is a project from 2020-2025 and orientation to 2030 to support farmers, cooperatives, and enterprises to invest in organic production. The state also sets organic agriculture standards for many crops, livestock, and fisheries.

\begin{tabular}{|c|c|c|c|c|}
\hline Content & Model & $\begin{array}{l}\text { Tan Dat Cooperative, } \\
\text { Vĩnh Long Province }\end{array}$ & $\begin{array}{l}\text { Tan Hiep District, } \\
\text { Kiên Giang } \\
\text { Province }\end{array}$ & $\begin{array}{c}\text { My Xuyen } \\
\text { District, Soc } \\
\text { Trang Province }\end{array}$ \\
\hline \multirow{2}{*}{ Total cost (mil. VND/ha) } & Organic & 22.55 & 28.62 & 20.30 \\
\hline & Inorganic & 18.98 & 20.86 & 19.52 \\
\hline \multirow{2}{*}{ Yield (ton/ha) } & Organic & 4.0 & 5,0 & 4,3 \\
\hline & Inorganic & 6.0 & 5,4 & 4,5 \\
\hline \multirow{2}{*}{ Selling price (VND/kg) } & Organic & 8,700 & 8,700 & 8,000 \\
\hline & Inorganic & 5,200 & 4,500 & 5,200 \\
\hline \multirow{2}{*}{ Profit (mil. VND/ha) } & Organic & 34.80 & 43.50 & 34.40 \\
\hline & Inorganic & 31.20 & 24.00 & 23.40 \\
\hline Profit difference (mil. VND) & & 3.60 & 1.95 & 1.10 \\
\hline
\end{tabular}

TABLE V: SWOT ANALYSIS FOR BUILDING AND DEVELOPMENT OF ORGANIC AGRICULTURE MODEL IN MEKONG DELTA, VIETNAM

\begin{tabular}{|c|c|}
\hline Strengths & Opportunities \\
\hline $\begin{array}{l}\text { - Potential of the land, shrimp-rice system, and indigenous trees. } \\
\text { - Labor availability. } \\
\text { - Farmers have experienced in rice cultivation. } \\
\text { - Availability of organic fertilizer sources. } \\
\text { - Advanced technologies have been developed for organic production. }\end{array}$ & $\begin{array}{l}\text { - Having great demand. } \\
\text { - It is suitable for the society and is a trend of the era. } \\
\text { - It is an attractive new business field. } \\
\text { - Have a supporting policy of the state and authorities at all levels. }\end{array}$ \\
\hline Weaknesses & Threats \\
\hline $\begin{array}{l}\text { - The market is not strong enough. } \\
\text { - High cost of inputs. } \\
\text { - High costs of certification. } \\
\text { - Production has not converged and still small. } \\
\text { - No distinction between safe and organic products. } \\
\text { - Lack of trust in the linking model. }\end{array}$ & $\begin{array}{l}\text { - Changing social perception and changing farming practices of } \\
\text { farmers is the biggest challenge. } \\
\text { - The challenge of weed management in organic rice farming is the } \\
\text { second challenge. } \\
\text { - High risk in investment. } \\
\text { - Unusual weather (climate change). } \\
\text { - Many competitors. } \\
\text { - Lack of good and certified organic inputs such as organic } \\
\text { pesticides, organic fertilizers. } \\
\text { - Productivity is not ensured in intensive farming when switching to } \\
\text { organic farming. }\end{array}$ \\
\hline
\end{tabular}


TABLE VI: MONITORING THE RISK SITUATION DUE TO FARMERS NOT COMPLYING WITH ORGANIC PRODUCTION PROCESSES WHEN PARTICIPATING IN THE MODEL Linking ORGANic Rice PRODUCTION AND CONSUMPTION IN THE MEKONG DelTA (2015-2020)

\begin{tabular}{|c|c|c|c|c|}
\hline Year & Area & $\begin{array}{c}\text { No. of participated } \\
\text { farmers }\end{array}$ & $\begin{array}{l}\text { No. of famers } \\
\text { broke the ruins }\end{array}$ & $\begin{array}{c}\text { Ratio } \\
(\%)\end{array}$ \\
\hline 2015 & Chau Thanh District, Tra Vinh Province & 45 & 4 & 7 \\
\hline 2017 & Cau Ngang District, Trà Vinh Province & 13 & 7 & 50 \\
\hline 2017 & A Minh District, Kien Giang Pronvince & 5 & 1 & 20 \\
\hline 2017 & Thoai Son District, An Giang Province & 3 & 1 & 33 \\
\hline 2018 & Thoi Binh District, Cà Mau Province & 14 & 5 & 36 \\
\hline 2019 & Tri Ton District, An Giang Province & 3 & 1 & 33 \\
\hline \multirow[t]{4}{*}{2020} & U Minh Thuong District, Kien Giang Province & 22 & 10 & 45 \\
\hline & Lowest & 3 & 1 & 7 \\
\hline & Highest & 45 & 10 & 50 \\
\hline & Average & 15 & 4.1 & 32 \\
\hline
\end{tabular}

Besides, due to the increasing demand for organic products, which is an important trending now not only in the world but also in the country, it opens up great opportunities for organic production and trading. According to a review of the Rodale Institute, the consumer demand for organic products in the world is growing rapidly, at over $10 \%$ annually [9].

\section{CONCLUSION AND SUGgestion}

\section{A. Conclusion}

- Model of organic rice production "4 partners linkage" starting from 2015 until now has got good results.

- Organic agriculture still faces many difficulties and threats at the beginning but many of them have been solved out. First of all, that is the success of organic rice production in the shrimp-rice area with the potential of hundreds of thousands of hectares. Then, the replication of organic rice production in the intensive practice areas and the replication of organic production for other crops which have high economic value.

- Organic rice production increases profits by 6 to 10 million $\mathrm{VND} / \mathrm{ha}$ compared to conventional inorganic rice production.

- Organic products will maintain the reputation of the domestic market as well as export, affirming an advantage of Vietnamese agriculture in the international market.

- Also contribute to protecting public health and maintaining a clean and sustainable environment.

\section{B. Suggestion}

- Complete soon the organic agriculture policy and mark the organic Vietnamese organic products compatible with international organic products.

- Create favorable conditions for private and international organizations to participate in organic certification according to regulations and create a fairly international competition. Organic certification organizations need to remove the "technical barriers" that make it more difficult and costly for organic production.

- Certification of organic inputs such as domestic fertilizers and plant protection products.

- Planning on organic production areas of rice and other crops of high economic value (pepper, cashew, cocoa, coffee, fruit trees, and vegetables).

- Develop the organic village, organic district, and organic province.

- Develop the market for organic agricultural products.

- Organize research and training systems related to organic agriculture.
- Maintain and develop high yield, good quality crop varieties such as ST 25 rice.

- Continue to promulgate policies to encourage businesses, individuals, and farmers to invest in organic agriculture such as subsidizing the cost of soil, water, product analysis, training, and certification costs.

- Support for the use of organic agricultural land in the planned area with the long-term provision and land consolidation.

- Support for the promotion of organic products through communication channels, social networks, and product introduction at domestic and international fairs, exhibitions, and conferences.

- Reward individuals and organizations with good contributions in organic agricultural research and development.

\section{ACKNOWLEDGMENT}

The work was a part of the project supported by Oxfam in Vietnam (Right to Food; GRAISEA 2, etc.). We are very grateful to Oxfam in Vietnam and also very grateful to the esteemed reviewers for their time and expert opinion.

\section{REFERENCES}

[1] Nguyen Cong Thanh (2018). Hướng dẫn sản xuất lúa hữu cơ cho các bên liên quan trong mô hình liên kết chuỗi giá trị. Nhà xuất bản Nông nghiệp, 2018. Trang 24-25 (Vietnamese).

[2] Wood, S., Sebastian, K. and Scherr, S.J. (2001). Pilot Analysis of Global Ecosystems: Agroecosystems. World Resources Institute, Washington DC.

[3] Millennium Ecosystem Assessment 2005. Millennium Ecosystem Assessment Synthesis Report. Island Press, Washington DC.

[4] Tilman, D. (1999). Global environmental impacts of agricultural expansion: the need for sustainable and effi cient practices. Proceedings of the National Academy of Sciences of the United States of America. 96(11): 5995-6000.

[5] United Nations Thematic Group. Sub-Group Meeting on Wildlife, Biodiversity and Organic Agriculture Ankara, Turkey, 15-16 April 2003. Organic agriculture: the challenge of sustaining food production while enhancing biodiversity.

[6] Kristiansen, P.; Taji, A. and Reganold, J. (2006). Organic agriculture: opportunities and challenges. In: Kristiansen, P.; Taji, A. and Reganold, J. (Eds.) Organic Agriculture: a Global Perspective. CSIRO Publishing, Collingwood, chapter 18, pp. 421-441.

[7] Halberg, N., Alrøe, H.F. and Kristensen, E.S. 2005a. Synthesis: perspectives for organic agriculture in a global context. In: Halberg, N., Alrøe, H.F., Knudsen, M.T. and Kristensen, E.S. (eds) Global Development of Organic Agriculture: Challenges and Promises. CAB International, Wallingford. pp. 344-368.

[8] Nguyen Cong Thanh, Tran Thi Tuyet Van, Duong Van Hay (2019). Analysis of price, cost price and efficiency of organic rice production from 2015 to 2018 in the Mekong Delta, Vietnam. Discovery Agriculture, Vol 5, 2019. Pp. 204-205. 
[9] Rodale Institute (Online 13/02/2021).

https://rodaleinstitute.org/blog/key-challenges-to-growing-the-

organic-movement/. Key challenges to growing the organic movement. 